\title{
Citizenship Without Magic
}

\author{
Lois Harder
}

I share Costica Dumbrava's critique of ius sanguinis citizenship, and ultimately what is, I think, his rejection of birth as the basis for political membership generally. Of course, there are issues of practicality - of the world as we find it - that might limit whether and how one would advance the abolishment of birthright citizenship in light of specific political dynamics. But it is precisely those practicalities, and the near unthinkability of alternatives to birth-based citizenship that demand our interrogation of birthright in the first instance. As Joseph Carens has argued with respect to his advocacy of open borders, 'even if we must take deeply rooted social arrangements as givens for purposes of immediate action in a particular context, we should never forget about our assessment of their fundamental character. Otherwise we wind up legitimating what should only be endured'.

In his contribution to this Forum, Rainer Bauböck defends birthright citizenship and argues that in both of its iterations (ius sanguinis and ius soli) it avoids political division and 'creates a quasi-natural equality of status' among citizens who are entitled to claim it. But what about the inequality that divides the entitled from the unentitled? Political communities may be unavoidably bounded, but if a normative commitment to human rights is our guiding frame, it seems incumbent upon us to advance methods or prospects for membership that reduce the barriers to belonging as much as possible. Moreover, as Jacqueline Stevens trenchantly observes, in defining the bounds of equal citizenship, borders also form the boundaries of our non-emergency expressions of compassion. ${ }^{2}$ To the extent that birthright entitlement advances a seemingly unassailable claim to exclusionary membership, its advocacy runs counter to a broader commitment to humanitarianism.

1 Carens, J. (2013), The Ethics of Immigration. New York: Oxford University Press, 229.

2 Stevens, J. (2010), States without Nations: Citizenship for Mortals. New York: Columbia University Press, 9. 
Bauböck's description of birthright citizenship evades the fact that establishing citizenship through birth, as with any other basis for membership, is an inherently political decision. One of the central appeals of birthright is that it involves innocent, vulnerable babies, infants who are not (yet) marked by misdeeds, criminality, inadequate knowledge or commitment, or the wrong ideological proclivities. It is this innocence that helps to obscure the profoundly political basis of birthright; that makes it possible to describe birthright citizenship as avoiding political division and establishing a quasi-natural equality. However, the use of criteria of birth to determine political membership - whether it is birth to a citizen parent (variously defined) or birth in the territory (variously defined) - is not innocent. Prevailing views about

- wedlock and patriarchal forms of social organisation (e.g. unwed mothers having responsibility for their children and conferring citizenship, but unwed fathers having no such responsibility or capacity);

- the relative significance of biological and social parenting as well as gender and sexuality (can a lesbian co-mother confer citizenship on her genetic progeny to whom she did not give birth - just as fathers do?);

- national attachment (is this child born abroad as second or subsequent generation?); and

- how generous territorial definitions should be (is a child born to a Ugandan mother on an American airline flying in Canadian airspace from Amsterdam to Boston a Canadian? Answer $=$ yes) ${ }^{3}$

all play out in the rules that determine birthright entitlement. The magical power of birthright citizenship is that it makes it possible for us to know and rehearse these rules while simultaneously making birthright seem straightforward, static and apolitical. In contrast to citizenship debates that engage migration, legal and illegal status and naturalisation, birthright citizenship makes these political choices disappear with a wave of a wand.

I am currently researching a book on the lost Canadians. These are people who thought they had a birthright claim to Canadian citizenship, but subsequently learned that they were mistaken. Their difficulties arose

3 'Birth and joy midflight' Boston Globe, 1 January 2009, available at http:// www.boston.com/news/local/massachusetts/articles/2009/01/01/birth_and_ joy_midflight/?page $=$ full 
for various reasons, and have now largely been resolved through statutory amendment (a rule change). In making their case to Parliament, the courts and the media, their primary, and highly successful, strategy, was to denigrate the rule-boundedness of 'mean-minded bureaucrats' and advance the merits of their claims through appeals to lineage and blood-based belonging. ${ }^{4}$ Despite being born in the UK, residing in Canada for five years as a small child, and having subsequently lived in the UK for six decades, one such lost Canadian insisted, 'I, sir, am a Canadian. To the roots of me, to the spirit of me, to the soul of me, I'm Canadian'. ${ }^{5}$ This impassioned claim to Canada - not exactly your 'go to' example of an ethnic nation - nonetheless succeeds as a rhetorical strategy because it re-enchants the nation, ${ }^{6}$ underscoring the country's desirability to the Canadian public, and insisting that this connection is an essential feature of her identity. This is a logic that only works in a world of birthright citizenship. And it is a strategy that eventually succeeded in securing legislative amendments, because the birth-based claims of the lost Canadians (and not necessarily residency or connection) carried an overwhelming political potency.

To the extent that birthright citizenship enables progressive people to cordon off a substantial portion of membership determination from a potentially nasty political debate, one can certainly understand its attractions. But the occlusion of politics with an unsupportable appeal to nature is ethically dubious. If we are committed to democratic equality, we need principles to manage how we live together that refuse the privilege of birth over naturalisation, and that require us to come to terms with our mortality. ${ }^{7}$ Political membership should be a lively, on-going process of negotiation in which everyone has a stake. Some critics might argue that abandoning birthright citizenship and its intergenerational character will create the conditions for decision making in which we are no longer future-oriented, or indeed, that we will neglect the lessons and obligations of our past. If our children do not

4 Canada, 26 February 2007, House of Commons Standing Committee on Citizenship and Immigration 39th Parliament 1st Session no. 38. (at 11:50).

5 Canada, 26 February 2007, House of Commons Standing Committee on Citizenship and Immigration 39th Parliament 1st Session no. 38. (at 11:45).

6 Honig, B. (2001), Democracy and the Foreigner. Princeton: Princeton University Press, 74.

7 For a full elaboration on the dangers of intergenerational citizenship, see Stevens (2010), at n.2 above. 
have a stake in the polity to come, why should we commit ourselves to making it better? This kind of argument is morally bereft. We can continue to care about the future and attend to the damages we, and our ancestors, have wrought, even if, or precisely because, our political membership is limited by our mortality. It was, of course, ever thus.

Open Access This chapter is licensed under the terms of the Creative Commons Attribution 4.0 International License (http://creativecommons.org/licenses/by/4.0/), which permits use, sharing, adaptation, distribution and reproduction in any medium or format, as long as you give appropriate credit to the original author(s) and the source, provide a link to the Creative Commons license and indicate if changes were made.

The images or other third party material in this chapter are included in the chapter's Creative Commons license, unless indicated otherwise in a credit line to the material. If material is not included in the chapter's Creative Commons license and your intended use is not permitted by statutory regulation or exceeds the permitted use, you will need to obtain permission directly from the copyright holder.

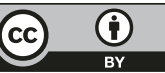

